\title{
Knowledge Management in a Globalized World and the Coronavirus Age
}

\author{
Jana Pechova ${ }^{1 *}$, Lenka Stejskalova ${ }^{1}$ and Hana Volfova $^{1}$ \\ ${ }^{1}$ SKODA AUTO University, Na Karmeli 1457, 29301 Mlada Boleslav, Czech Republic
}

\begin{abstract}
.
Research background: Although the world is still in a coronavirus crisis, it also sees hope in vaccines being developed, government measures taken to revive the economy and borders reopening. At the same time, the globalized world has learned a lot. Knowledge management and knowledge sharing in a globalized world now have even higher mission than before, since work regimes have completely changed and the necessary requirements for the protection of employees' health and safety are being adopted.

Purpose of the article: Knowledge management is a multidisciplinary activity; its individual disciplines will be described, characterized and researched. Research surveys will map the activities of knowledge management in new work regimes with the protection of employee health and safety in order to optimize knowledge management of businesses in a globalised world with existing threats.

Methods: After the questionnaire survey is completed, the respondents' answers will be encoded in Microsoft Excel. The encoded data will be exported to the SPSS statistical software. The objective of the statistical evaluation is to extract relationships and linkages that could contribute to optimising the knowledge management of enterprises in a globalised world. To detect basic relationships and linkages, Pearson's chi-square test of independence will be used at the level of descriptive statistics, using contingency tables.

Findings \& Value added: Based on the conducted research, it diagnoses existing knowledge management barriers and knowledge sharing in globalized enterprises.
\end{abstract}

Keywords: globalization; globalized world; knowledge management; know-how

JEL Classification: $M 54$; $M 51$; $I 15$

\footnotetext{
*Corresponding author: jana.pechova@savs.cz
} 


\section{Introduction}

Knowledge Management deals with the generation, dissemination, preservation and revision of common expertise [1]. Knowledge Management does not replace nor compete with any of the managerial directions, but it permeates all managerial activities. Even if it is not a new discipline, at present it is gaining greater importance than before. The research survey pursued objective, specifically the focus on the generation, dissemination, preservation and effective use of common expertise in new work regimes connected with the requirements for the health and safety of employees, (e.g. home office) in globalized enterprises [2]. Based on the conducted research, it diagnoses existing knowledge management barriers and knowledge sharing in globalized enterprises.

\subsection{Knowledge management}

Management as a discipline has the aim of generating valid knowledge but has been schizophrenic as to how this should be achieved [3]. Knowledge, as a structured summary of interrelated ideas, findings and experience from a particular area, or for a specific purpose, are the assets of each business organisation. However, unlike common tangible assets, the company does not own the range of knowledge possessed by a particular worker or a group of people. Knowledge management is a part of management focused on the use of knowledge to increase the efficiency of activities of the company. Knowledge is more than data, information and findings [4]. It is a foreign concept, based on international management, focusing on knowledge sharing, as a key area [5], but still burdened by many obstacles, such as inadequate flow of knowledge between management members, superiors and employees or directly in working teams. In some cases, conflicts in knowledge transfer and application can be useful, but only if it is a task conflict in the flow of knowledge and not a process conflict [6].

\subsubsection{Data, Information, Knowledge}

The term data refers to all experiences from the environment that can be captured by the human senses. Hard data is represented by data that is clearly defined and quantified (numerically, in physical, economic units). Soft data express people's opinions and attitudes [4]. Another approach says - the knowledge can be broadly classified into two categories, first tacit knowledge, and second explicit knowledge. Tacit knowledge is difficult to express in the form of language, symbol. Tacit knowledge cannot be stored or expressed in the form of any written material. This knowledge is non-transferable. Explicit knowledge can be stored as data and symbols and can be transmitted within the organizations [7]

If the data is processed artificially, it is called information, which is specifically classified by the user in a special category and thus acquires a unique meaning. This means that the information represents a logically categorised set of data that will be used for some purpose. $[8,9]$.

Any form of representation of practical information is knowledge, which will actively help an individual to perform tasks and manage related cognitive and analytical processes [10]. Quality knowledge is always composed of a complex combination of data, skills, information, expert opinions and empirical experience. This union leads to the creation of a valuable but at the same time intangible asset, which can be used effectively as a basis for a managerial decision-making process. It is necessary to mention a significance of knowledge data sharing in general. Knowledge sharing can both benefit the firm with access to external knowledge and skill sets and expose it to potential risks of knowledge leakage and misappropriation, thus both advancing and hampering the innovation performance [11]. 
Therefore, the level of sharing and the level of individual use of knowledge must always be carefully considered.

Any knowledge is tied and linked to an appropriate carrier [12]. In recent years, great emphasis has been placed, for example, on networks for the development of early careers of professionals and the creation of their knowledge [13] According to a latest study [14] we also know, that improving knowledge flows between co-workers affects productivity. Directing co-workers to share knowledge raised average productivity and reduced output dispersion between workers, highlighting the role that management practices play in generating spillovers inside the firm. A real/tangible/actual carrier of the content of knowledge information can be, for example, a group of people, a person or a formal organisation; last but not least, discrete expressions of knowledge are placed on a material medium or an electronic device. The pieces of information can also exist and be transferred in an intangible, formal form similar to ownership or a patent [14].

\subsection{Disciplines of Knowledge Management}

Knowledge Management is a systematic approach to finding, selecting, organizing and using knowledge in a business to create value, improve its performance and achieve strategic goals. Knowledge Management is a multidisciplinary activity, and it deals with information science, interpersonal communication, education, internal communication, process approach, content management, document management and information technologies of the company [15]. These disciplines mentioned above were mapped in the questionnaire survey, which is dealt with in Chapter 2. It reflects also a local situation - in our conditions, however, we still encounter some problems, many of them are given culturally. One of these obstacles is the conflict of motives that arise from knowledge management processes especially within knowledge sharing. It is deeply rooted in the socio-cultural system [16], often affected by cultural distance in the sense of receiving and using international knowledge [17] and based on the level of cultural intelligence as a positive impact to knowledge sharing [18]. Another problem could be the motivation of recipients - higher knowledge recipient's intention to adopt knowledge can enhance cognitive learning. It is very important to understand how to utilize the knowledge flow for employees with different intentions to adopt knowledge. The recipients may not want to accept the knowledge and, conversely, many workers may not be willing to share their knowledge - the motivation plays an important role in this process [19]. In today's turbulent globalized world, therefore, increased attention needs to be paid to all aspects of knowledge transfer and its effective use.

\section{Methods}

From 14th-21st April 2020, a questionnaire survey was conducted. It was based on the specified objectives and individual disciplines of the Knowledge Management as described in Chapter 1.2. The questionnaire contained a total of 21 questions that mapped the specific disciplines of Knowledge Management, i.e. processes, IT and communication infrastructure, human resources and their competence, and formal and informal workplace organisation. Two hundred seventy respondents participated in the survey, all from ŠKODA AUTO University partner companies in the Czech Republic, Slovakia, Russia and China. The aim of the research survey was to diagnose existing barriers to knowledge management and sharing of experience in a globalized world marked by the COVID-19 pandemic. 


\subsection{Methodology of the questionnaire survey}

After the completion of data collection, the individual responses of the respondents were encoded. Data encoding was performed in Microsoft Excel. All variables were, by default, encoded into numeric variables. The encoded data was exported into the SPSS statistical software in which the encoding framework was created, including the resolution of individual variables. The aim of the statistical data evaluation was to extract relationships and linkages that might contribute to better understanding of knowledge management processes. Dependencies with an exogenous quantity were tested. These are quantities determined outside the examined system - age of the respondents, area and length of their employment, educational background and the size of the company. These variables do not intervene in the functioning of Knowledge Management; however, there may be a tendency to influence it. It cannot be assumed that, for better information processes, adjusting the age structure of employees, for example, would lead to better information processes. Thanks to this analysis, however, it is possible to set different processes against specific sociodemographic groups of stakeholders.

To detect basic relationships and linkages, Pearson's chi-square test of independence was used at the level of descriptive statistics, using contingency tables. Only relationships with asymptotic significance lower than 0.05 were recorded. If a value lower than 0.05 is reached between two variables, it can be claimed a relationship exists. However, the chisquare test does not say anything else about the nature of the relationship between variables, and it cannot be assumed that all relationships are significant enough to be generalised. Usually, correlation would be subsequently applied; however, its relation to exogenous quantities has no information value. In terms of the depth of analysis, proving the closeness of the relationship between age and the optimal person to train a new worker would not yield any specific applicable knowledge. For the interpretation of the research to be meaningful, it is necessary to know whether the relationship is conclusive in relation to the different age categories. For this reason, the so-called adjusted residues were used in the contingency tables. The adjusted residue is based on the difference between empirical and expected frequency, which at the time of its value is greater than 2.00 (or -2.00 for negative-oriented relationship), we can be sure (with $95 \%$ probability) that the difference between frequencies did not arise by accident. In the case of values greater than or equal to 3.29 (or -3.29 for negative-oriented relationships), the probability of accidental occurrence of the deviation is less than $0.1 \%$. Adjusted residues therefore determine the extent to which the presumption of independence is violated, which is satisfactory for the purpose of evaluating these variables. In this way, it is possible to prove not only the relationship of the endogenous question with the socio-demographic indicator, but also to specify to which internal categories these significant relationships apply. Again, only relationships of statistical significance were left; outliers were excluded.

By analysing of the contingency tables and vicariously adjusted residues, relationships were extracted where it can be assumed that they may affect the knowledge management system. Consequently, it can be considered that this influence will be at least partially predictable and therefore applicable in practice.

\section{Questionnaire Survey Results}

The results of the research are presented in the form of a table showing the survey questions, exogenous variables, dependent variables and closeness of the relationship between them. As previously mentioned, only statistically significant relationships were left, and the outliers were excluded. Table 1 presents variables with proven dependency according to the size of the business in which respondents are employed. The same 
methodology was applied to processing the variables with proven dependence on age of the respondents, area and length of their employment, educational background and the size of the company.

The COVID-19 pandemic has entered the lives of each individual and has paralyzed many aspects of the day-to-day operations of companies in global and local markets. From the vision of a global citizen living, working and consuming goods and services across borders, we have become citizens of a hermetic society overnight.

The questionnaire survey took place on 14-21 April 2020, at a time when a state of emergency was in place in the Czech Republic and people were forced, not only in the Czech Republic, to work from home. The COVID-19 epidemic essentially tested the level of functioning of knowledge management in most businesses.

Table 1. Variables with proven dependency according to a business size

\begin{tabular}{|c|c|c|c|}
\hline $\begin{array}{l}\text { Question in the } \\
\text { questionnaire survey }\end{array}$ & $\begin{array}{l}\text { Exogenous } \\
\text { variable }\end{array}$ & Dependent variable & $\begin{array}{l}\text { Adjusted. } \\
\text { res. }\end{array}$ \\
\hline $\begin{array}{l}\text { Do you know where to find } \\
\text { important information for } \\
\text { your job? }\end{array}$ & $\begin{array}{c}\text { up to } 50 \\
\text { employees }\end{array}$ & no & 2.6 \\
\hline \multirow{3}{*}{$\begin{array}{l}\text { Indicate where important } \\
\text { information for your job is } \\
\text { stored. }\end{array}$} & $\begin{array}{c}\text { up to } 50 \\
\text { employees }\end{array}$ & internet (cloud) & 2.7 \\
\hline & $\begin{array}{l}\text { up to } 250 \\
\text { employees }\end{array}$ & (internal) shared data storage & 2.3 \\
\hline & $\begin{array}{c}\text { more than } 250 \\
\text { employees }\end{array}$ & internet (cloud) & -2.2 \\
\hline $\begin{array}{l}\text { How often do you use } \\
\text { information that is shared } \\
\text { and which is important for } \\
\text { your job content? }\end{array}$ & $\begin{array}{c}\text { up to } 50 \\
\text { employees }\end{array}$ & often & 2.7 \\
\hline \multirow{2}{*}{$\begin{array}{l}\text { To what extent are you } \\
\text { satisfied with information } \\
\text { relevant to your job? }\end{array}$} & $\begin{array}{c}\text { up to } 50 \\
\text { employees }\end{array}$ & satisfaction & 2.8 \\
\hline & $\begin{array}{l}\text { up to } 250 \\
\text { employees }\end{array}$ & maximum satisfaction & 2.6 \\
\hline \multirow{2}{*}{$\begin{array}{l}\text { Via which channel do you } \\
\text { most often communicate } \\
\text { with your colleagues or } \\
\text { supervisors? }\end{array}$} & $\begin{array}{c}\text { up to } 50 \\
\text { employees }\end{array}$ & social networks & 2.7 \\
\hline & $\begin{array}{c}\text { more than } 250 \\
\text { employees }\end{array}$ & e-mail & 3 \\
\hline \multirow{2}{*}{$\begin{array}{l}\text { Do you want to } \\
\text { communicate with your } \\
\text { colleagues or superiors via } \\
\text { another channel? }\end{array}$} & $\begin{array}{c}\text { up to } 50 \\
\text { employees }\end{array}$ & no & 3.1 \\
\hline & $\begin{array}{c}\text { more than } 250 \\
\text { employees }\end{array}$ & yes & 2.6 \\
\hline \multirow{2}{*}{$\begin{array}{l}\text { Who do you consider to be } \\
\text { the optimal person for } \\
\text { training when switching to } \\
\text { a new work regime (e.g. } \\
\text { Home Office)? }\end{array}$} & $\begin{array}{l}\text { up to } 250 \\
\text { employees }\end{array}$ & superior (chief) & 2.6 \\
\hline & $\begin{array}{c}\text { more than } 250 \\
\text { employees }\end{array}$ & colleague & 2.9 \\
\hline \multirow{2}{*}{$\begin{array}{l}\text { Who don't you consider to } \\
\text { be the optimal person for } \\
\text { training when switching to } \\
\text { a new work regime }(\mathrm{e} . \mathrm{g} \text {. }\end{array}$} & $\begin{array}{l}\text { up to } 250 \\
\text { employees }\end{array}$ & coordinator & 2.9 \\
\hline & more than 250 & personnel manager & 2.7 \\
\hline
\end{tabular}




\begin{tabular}{|c|c|c|c|}
\hline Home Office)? & employees & & \\
\hline \multirow{3}{*}{$\begin{array}{l}\text { What know-how is } \\
\text { necessary for your work? }\end{array}$} & $\begin{array}{l}\text { up to } 50 \\
\text { employees }\end{array}$ & $\begin{array}{l}\text { presentation and communication } \\
\text { skills }\end{array}$ & 3.4 \\
\hline & $\begin{array}{l}\text { up to } 250 \\
\text { employees. }\end{array}$ & $\begin{array}{c}\text { computer technology - routine } \\
\text { work }\end{array}$ & 2.9 \\
\hline & $\begin{array}{c}\text { more than } 250 \\
\text { employees }\end{array}$ & $\begin{array}{c}\text { computer technology - routine } \\
\text { work }\end{array}$ & 2.6 \\
\hline \multirow{2}{*}{$\begin{array}{l}\text { What types of information } \\
\text { is necessary when } \\
\text { switching to a new work } \\
\text { regime, e.g. Home Office? }\end{array}$} & $\begin{array}{l}\text { up to } 50 \\
\text { employees }\end{array}$ & guidelines / manuals & -3.4 \\
\hline & $\begin{array}{l}\text { up to } 250 \\
\text { employees }\end{array}$ & guidelines / manuals & 3.1 \\
\hline $\begin{array}{l}\text { Are there any types of } \\
\text { information that are } \\
\text { redundant on shared data } \\
\text { storage? }\end{array}$ & $\begin{array}{c}\text { up to } 50 \\
\text { employees }\end{array}$ & no & 3.2 \\
\hline
\end{tabular}

Source: Own survey, 2020

Table 2 presents variables with proven dependency by the area of employment of the respondents.

Table 2. Variables with proven dependency by the area of employment of the respondents

\begin{tabular}{|c|c|c|c|}
\hline $\begin{array}{l}\text { Question in the } \\
\text { questionnaire } \\
\text { survey }\end{array}$ & Exogenous variable & Dependent variable & $\begin{array}{l}\text { Adjusted. } \\
\text { res. }\end{array}$ \\
\hline \multirow{2}{*}{$\begin{array}{l}\text { Do you know where } \\
\text { to find important } \\
\text { information for } \\
\text { your job? }\end{array}$} & banking & no & 2,6 \\
\hline & $\begin{array}{c}\text { education and } \\
\text { development }\end{array}$ & no & 2,6 \\
\hline \multirow{2}{*}{$\begin{array}{l}\text { How often do you } \\
\text { use information } \\
\text { that is shared and } \\
\text { which is important } \\
\text { for your job } \\
\text { content? }\end{array}$} & $\begin{array}{l}\text { education and } \\
\text { development }\end{array}$ & almost never & 2,8 \\
\hline & IT & often & 3,1 \\
\hline \multirow{3}{*}{$\begin{array}{l}\text { Via which channel } \\
\text { do you most often } \\
\text { communicate with } \\
\text { your colleagues or } \\
\text { supervisors? }\end{array}$} & automotive & email & 2,4 \\
\hline & $\begin{array}{c}\text { education and } \\
\text { development }\end{array}$ & oral report & 2,9 \\
\hline & telecommunication & MS Teams & 3,1 \\
\hline \multirow{5}{*}{$\begin{array}{l}\text { Do you want to } \\
\text { communicate with } \\
\text { your colleagues or } \\
\text { superiors via } \\
\text { another channel? }\end{array}$} & automotive & yes & 2,7 \\
\hline & banking & yes & 2,6 \\
\hline & $\begin{array}{c}\text { education and } \\
\text { development }\end{array}$ & no & 2,6 \\
\hline & IT & no & 2,7 \\
\hline & electrotechnics & yes & 2,4 \\
\hline Who do you & automotive & colleague & 2,8 \\
\hline
\end{tabular}




\begin{tabular}{|c|c|c|c|}
\hline \multirow{3}{*}{$\begin{array}{l}\text { consider to be the } \\
\text { optimal person for } \\
\text { training when } \\
\text { switching to a new } \\
\text { work regime (e.g. } \\
\text { Home Office)? }\end{array}$} & banking & personnel manager & 2,9 \\
\hline & $\begin{array}{l}\text { education and } \\
\text { development }\end{array}$ & coordinator & 3,1 \\
\hline & IT & superior (chief) & 2,6 \\
\hline \multirow{4}{*}{$\begin{array}{l}\text { Who don't you } \\
\text { consider to be the } \\
\text { optimal person for } \\
\text { training when } \\
\text { switching to a new } \\
\text { work regime (e.g. } \\
\text { Home Office)? }\end{array}$} & $\begin{array}{l}\text { education and } \\
\text { development }\end{array}$ & colleague & 2,4 \\
\hline & IT & personnel manager & 2,8 \\
\hline & market research & superior (chief) & 3 \\
\hline & telecommunication & superior (chief) & 2,7 \\
\hline \multirow{2}{*}{$\begin{array}{l}\text { Are there any types } \\
\text { of information that } \\
\text { are redundant on } \\
\text { shared data } \\
\text { storage? }\end{array}$} & banking & yes & 2,8 \\
\hline & IT & yes & 2,8 \\
\hline
\end{tabular}

Source: Own survey, 2020

Table 3 presents variables with proven dependency by the age of the respondents.

Table 3. Variables with proven dependency by the age of the respondents

\begin{tabular}{|c|c|c|c|}
\hline $\begin{array}{l}\text { Question in the } \\
\text { questionnaire } \\
\text { survey }\end{array}$ & Exogenous variable & Dependent variable & $\begin{array}{l}\text { Adjusted. } \\
\text { res. }\end{array}$ \\
\hline \multirow{4}{*}{$\begin{array}{l}\text { Indicate where } \\
\text { important } \\
\text { information for } \\
\text { your job is } \\
\text { stored. }\end{array}$} & to 25 years & (internal)shared data storage & 2,7 \\
\hline & $26-40$ years & paper form & 2,6 \\
\hline & $41-50$ years & intranet/portal & 3,2 \\
\hline & more than 50 years & (internal)shared data storage & 2,9 \\
\hline \multirow{4}{*}{$\begin{array}{l}\text { How often do } \\
\text { you use } \\
\text { information } \\
\text { that is shared } \\
\text { and which is } \\
\text { important for } \\
\text { your job } \\
\text { content? }\end{array}$} & to 25 years & almost never & 3 \\
\hline & $26-40$ years & very often & 2,6 \\
\hline & $41-50$ years & often & 2,9 \\
\hline & more than 50 years & average & 3,1 \\
\hline \multirow{3}{*}{$\begin{array}{l}\text { To what extent } \\
\text { are you } \\
\text { satisfied with } \\
\text { information } \\
\text { relevant to } \\
\text { your job? }\end{array}$} & to 25 years & maximum satisfaction & 2,7 \\
\hline & $26-40$ years & disfatisfaction & 2,1 \\
\hline & $41-50$ years & satisfaction & 2,2 \\
\hline \multirow{2}{*}{$\begin{array}{l}\text { Via which } \\
\text { channel do you } \\
\text { most often } \\
\text { communicate }\end{array}$} & to 25 years & email & 3,1 \\
\hline & $26-40$ years & skype & 2,6 \\
\hline
\end{tabular}




\begin{tabular}{|c|c|c|c|}
\hline $\begin{array}{l}\text { with your } \\
\text { colleagues or } \\
\text { supervisors? } \\
\end{array}$ & $41-50$ years & skype & $-2,6$ \\
\hline \multirow{3}{*}{$\begin{array}{l}\text { Do you want to } \\
\text { communicate } \\
\text { with your } \\
\text { colleagues or } \\
\text { superiors via } \\
\text { another } \\
\text { channel? }\end{array}$} & $26-40$ years & yes & 2,1 \\
\hline & $41-50$ years & no & 2,5 \\
\hline & more than 50 years & yes & 2,6 \\
\hline \multirow{4}{*}{$\begin{array}{l}\text { Who don't you } \\
\text { consider to be } \\
\text { the optimal } \\
\text { person for } \\
\text { training when } \\
\text { switching to a } \\
\text { new work } \\
\text { regime (e.g. } \\
\text { Home Office)? }\end{array}$} & to 25 years & personnel manager & 3,4 \\
\hline & $26-40$ years & superior (chief) & 2,7 \\
\hline & $41-50$ years & superior (chief) & $-2,7$ \\
\hline & more than 50 years & coordinator & 2,8 \\
\hline \multirow{3}{*}{$\begin{array}{l}\text { Are there any } \\
\text { types of } \\
\text { information } \\
\text { that are } \\
\text { redundant on } \\
\text { shared data } \\
\text { storage? }\end{array}$} & to 25 years & no & 3,1 \\
\hline & $26-40$ years & yes & 2,3 \\
\hline & $41-50$ years & no & 3 \\
\hline
\end{tabular}

Source: Own survey, 2020

In the last century, it was sufficient to win over competition by introducing new production facilities or new technology, Nowadays, it is not only the latest technology, but also knowledge. Managers and employees of the companies we contact agree on the importance of knowledge management (in particular when the globalized world has experienced the closure of borders and completely new work regimes) and already apply many elements of it. When examining individual knowledge management disciplines through a questionnaire survey carried out in April 2020, several barriers were identified that prevent the strengthening of existing Knowledge Management: The research focused on the relationships between individual Knowledge Management activities and individual variables such as company size or the duration of employment in the company. Based on these relationships, existing barriers to knowledge management and knowledge sharing in a globalized world have been defined. Research conducted in April 2020 revealed the following barriers to knowledge management and knowledge sharing:

1. It is not possible to clearly and unequivocally define the limits of applied knowledge in a company working in the fields of education and development as well as banking.

2. The disincentive factor in the form of unwillingness to share the knowledge of employees aged 26-40 years and in the field of education and development as well as banking presents a problem.

3. In the IT and banking business areas, redundant information existing on shared data storage that influences the effective way of searching for knowledge creates procedural disorganisation.

4. IT support is rarely employed. The respondents of the age group $26-40$ still use paper documentation to preserve important information related to their work. 
5. Information may be contradictory, in particular in enterprises with more than 250 employees.

6. The communication culture needs to be addressed, in particular in the area of automotive industry, where the respondents wish to communicate via a channel other than e-mail.

7. Knowledge Management lacks dedicated staff creating systemic support for respondents within; at present the support is as a rule created by colleagues or superiors, within or outside.

\section{Conclusion}

The paper The Problem of Fluctuation and Knowledge Management focused on individual disciplines of Knowledge Management and presents the results of a questionnaire survey carried out in April 2020. The results of the questionnaire survey revealed several obstacles in the existing disciplines of Knowledge Management:

1. Inaccurately defined knowledge application in the company.

2. Demotivating factor for sharing information.

3. Redundant information on shared storage.

4. Low level of employing IT tool.

5. The problem of conflicting information.

6. Culture of the company's communication and an unsatisfactory communication channels for employees.

7. Lack of responsibility of appointed employees in creating system support.

If managers focus on examining the identified barriers, it is possible to strengthen Knowledge management in both, the new work regimes related to employee's health and safety, such as home office, necessary social separation in similar threats to COVID-19, closing borders of a globalized world, as well as, for example, the departure or illness of skilled and qualified workers.

\section{References}

1. Hronik, F. (2007). Rozvoj a vzděláváni pracovníků. Praha: Grada Publishing.

2. Bencsik, A., Machova, R. (2012). Knowledge management and ethics from the business point of view. In The 6th International Days of Statistics and Economics: Conference Proceedings. Prague: University of Economics. 124-136.

3. Mingers J. (2015). Management Knowledge and Knowledge Management: Realism and Forms of Truth. In: Essentials of Knowledge Management. Palgrave Macmillan : London.

4. Veber, J. (2016). Management inovací. 1. vyd. Praha: Management Press.

5. Foss, N.J., Pedersen, T. (2019). Microfoundations in international management research: The case of knowledge sharing in multinational corporations. Journal of International Business Studies, 50(8), 1594-1621.

6. Hewitt, B., Walz, D., McLeod, A. (2020). The Effect of Conflict and Knowledge Sharing on the Information Technology Project Team Performance. International Journal of Knowledge Management, 16(1), 1-20. 
7. Agrawal, A., Mukti, S.A. (2020). Knowledge Management \& It's Origin, Success Factors, Planning, Tools, Applications, Barriers and Enablers: A Review. International Journal of Knowledge Management, 16(1), 43-82.

8. Bencsik, R., Machova R., Toth, Z. (2016). Cheap and clever - symbiosis of frugal innovation and knowledge management. Problems and Perspectives in Management, 14(1), 85-93.

9. Velinov, E., Kubicek, A. (2013). The role of top Managment Teams Heterogenity in the IPO Process. In 9th European Conference on Management Leadership and Governance. Klagenfurt, $325-331$.

10. Srisamran, P., Ractham, V.V., (2020). Impact of Knowledge Adoption and Cognitive Learning in the Knowledge Transfer Process. International Journal of Knowledge Management, 16(3), 1-16.

11. Zhang, J., Jiang, H., Wu, R., \& Li, J. (2019). Reconciling the Dilemma of Knowledge Sharing: A Network Pluralism Framework of Firms' R\&D Alliance Network and Innovation Performance. Journal of Management, 45(7), 2635-2665.

12. Hronik, F. (2007). Rozvoj a vzdelavani pracovniku. Praha: Grada Publishing.

13. Dunn, M. B. (2019). Early Career Developmental Networks and Professionals' Knowledge Creation. Journal of Management, 45(4), 1343-1371.

14. Sandvik, J., Saouma, R. Seegert N., \& Stanton, Ch. (2020). Workplace Knowledge Flows, The Quarterly Journal of Economics, 135(3), 1635-1680.

15. Novák, A. (2017) Inovace je rozhodnutí. Praha: Grada Publishing, a.s.

16. Bures, V., Brunet-Thorton, R. (2014). Confronting cultural barriers to knowledge management using a distinctive czech cultural model. In The 8th International Days of Statistics and Economics: Conference Proceedings, 229-240.

17. Shenkar, O., Tallman, S.B., Wang, H. (2020). National culture and international business: A path forward. Journal of International Business Studies, 51(8), 1-18.

18. Stoermer, S., Davies, S. \& Froese, F.J. (2020). The influence of expatriate cultural intelligence on organizational embeddedness and knowledge sharing: The moderating effects of host country context. Journal of International Business Studies, 51(7), 1-22.

19. Todorova, N., Mills, A. M., (2018). Why do People Share?: A Study of Intrinsic and Extrinsic Motivation to Share Knowledge in Organisations. Journal of International Business Studies, 14(3), 1-20. 